\title{
SMACKtivism: A Program Redesign So Good, You Won't Know What Hit You
}

\author{
Tiffany Karalis Noel \\ University at Buffalo, The State University of New York \\ tbkarali@buffalo.edu \\ Julie Gorlewski \\ University at Buffalo, The State University of New York \\ jgorlews@buffalo.edu \\ Erin Kearney \\ University at Buffalo, The State University of New York \\ ekearney@buffalo.edu
}

\begin{abstract}
This essay describes the context, mission, guiding principles, signature pedagogies, curriculum, and anticipated benefits and limitations of our newly designed EdD in Learning and Teaching in Social Contexts. As we prepare to launch our new program (pending approval), our key development efforts are focused on implementing leading-edge coursework centering on problems of practice through a blend of online interactions and applied, real-world experiences. Our primary objective is to equip scholar-practitioners with the expertise to initiate and sustain systematic approaches to transformative and justice-oriented improvement within their local educational communities, both during and following their time in the program.
\end{abstract}

KEYWORDS: program redesign, problems of practice, systematic approaches, justice-oriented, activism

\section{REIMAGINING OUR DOCTORAL PROGRAMS}

With today's expansive access to distance learning, also considered learning that takes place partially or entirely over the Internet, online course delivery provides users the flexibility to complete degree programs outside the constraints of time and place (Chaney, 2001; Gilbert, 2015; U.S. Department of Education, 2010). In the United States (U.S.), where $85.8 \%$ of males and $66.5 \%$ of females work more than 40 hours per week (U.S. Bureau of Labor Statistics, 2015), it is understandable that $48 \%$ of today's students are enrolled in fully online degree programs (Allen \& Seaman, 2017), which allow them to complete coursework requirements alongside a myriad of responsibilities. Correspondingly, for over a decade, universities in the U.S. have observed a dramatic growth of students who enroll in online courses (Halupa \& Bollinger, 2013). Between Fall 2008 and Fall 2009, the U.S. observed a 21\% increase in the number of students who were enrolled in online courses, which indicated that approximately 5.6 million students were enrolled in at least one online course (Allen \& Seaman, 2011). By 2010, the U.S. observed an additional $10 \%$ increase, which indicated that approximately $31 \%$ of students in higher education were enrolled in at least one online course - an ever-increasing growth rate that was not expected to taper off in the foreseeable future (Allen \& Seaman, 2011). In 2017, the National Center for Education Statistics reported that $33.7 \%$ of students in higher education were enrolled in online courses, which indicated that approximately 6.7 million students were enrolled in at least one online course (Snyder, de Brey, \& Dillow, 2019). Given the exponential growth of online students in the U.S., a reality that was observable in our online Curriculum, Instruction, and the Science of Learning PhD program at University at Buffalo, we determined that the addition of a fully online EdD program would offer current and prospective students an accessible and flexible opportunity for working professionals to earn an education doctorate.

In the 15 years since Arthur Levine's (2005) call to abolish the Doctor of Education degree, researchers such as Shulman, Golde, Bueschel, and Garabedian (2006) as well as the Carnegie Project on the Education Doctorate (CPED) consortium, which includes over 100 accredited institutions of higher education, have been working to reclaim the professional doctorate through dialogue, experimentation, critical feedback, and evaluation. Furthermore, with the ever-increasing demand for distance learning programs, many institutions now offer online EdD program options that deliver leading-edge content knowledge and research methods through a blend of online interactions and applied, real-world experiences to honor the local educational context of each student. Furthermore, in order to identify and address barriers to educational opportunity, institutions of higher education must take ownership of the ways in which academic cultural practices promote systemic inequities. As educational opportunities grow, the need for online programs that are
New articles in this journal are licensed under a Creative Commons Attribution 4.0 United States License.

ULS

This journal is published by the University Library System of the University of Pittsburgh as part of its D-Scribe Digital Publishing Program and is cosponsored by the University of Pittsburgh Press.

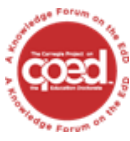

This journal is supported by the Carnegie Project on the Education Doctorate: A Knowledge Forum on the EdD (CPED) cpedinitiative.org 
responsive to an increasingly diverse student population must be balanced with an emphasis on maintaining excellence.

As we sought to reimagine our Curriculum, Instruction, and the Science of Learning $\mathrm{PhD}$ programs, we aimed to reciprocally develop equity and excellence within the curriculum to better align with our Graduate School of Education's mission:

With a focus on local-to-global impact, the Graduate School of Education is an inclusive community engaged in groundbreaking research and teaching across education, human development and information science that improves educational, social and economic opportunities for individuals and communities.

This required us to engage in multidimensional analysis related to the career goals of students, their learning needs, our own institutional norms, and disciplinary standards in the field. All of these dimensions were intentionally aligned with a commitment to activism toward equity and justice. Consistent with our mission as a public institution, faculty in the Department of Learning and Instruction (LAI) in the Graduate School of Education at University at Buffalo were united in the effort to expand opportunities while maintaining the high standards expected of an American Association of Universities (AAU) institution. We learned that this necessitated an approach to reform that was genuinely dialogic. To transform toward justice, we needed to be willing to examine and transform our own ways of thinking and acting. We needed to be in deeper dialogue with our current students in order to gain a sense of what activism would mean in their local contexts.

Through survey data collection and conversations with current $\mathrm{PhD}$ students, we found that many students with full-time work responsibilities and the need for distance learning flexibility sought an applied alternative to primarily theoretical $\mathrm{PhD}$ programs. In response to students' feedback, the department applied for and secured institutional membership with CPED, appointed a new director of doctoral studies, and collaborated to design a new EdD program during the 2019-20 academic year.

\section{Context for Designing a New EdD Program}

As educational scholars, we approached program revisions from a research perspective, with the overarching goal of addressing this query: How can a doctoral program in a public institution unify equity and excellence? Sub-questions included the following:

- How do students describe their experiences in our current Curriculum, Instruction, and the Science of Learning (CISL) PhD program?

- In what ways do our current CISL PhD align with departmental commitment to equity and justice?

- How do students describe the overall quality of the coursework they have taken in our current CISL PhD program?

- What are the desired careers students hope to pursue immediately following their graduation?

- How can curriculum maximize flexibility while ensuring that foundational courses in two broad fields, curriculum and instruction and learning sciences, are offered?
- How can we ensure that students have access to a broad range of methods courses, while also providing the depth necessary to equip them with research expertise?

Within our Department of Learning and Instruction, most doctoral students are enrolled in the CISL PhD program, which was established in 2013. While both on-campus and online options are available, the vast majority of students are enrolled in the fully online version. In May of 2019, a survey was sent out to all-approximately 250-doctoral students in the department. Of the one-third of students who responded, $60.5 \%$ were currently enrolled in the CISL online program, $65.4 \%$ held part-time student status, and $67.5 \%$ held full-time jobs in addition to pursuing their $\mathrm{PhD}$. When asked to rate elements of the doctoral program on a scale of importance, less than $40 \%$ of students said that earning a career in academia was important to them, and more than $60 \%$ of students said that applying what they learn in their workplace and local communities was of utmost importance to them. Finally, when introduced to the idea of a new EdD program focused on impacting educational problems of practice and field-focused research, student responses were enthusiastic:

Even with a PhD, some of us are not interested in faculty/research pathways in the traditional sense. We have jobs, families, and responsibilities...It's encouraging to learn that a new EdD will be added to the offerings.

I am very interested in the EdD option...I am interested in quantitative research or classroom action research.

I strongly agree that having an EdD program would direct more practice-oriented folks in a more productive direction for everyone.

I have such a good feeling about this transition, and I feel like a weight has been lifted. I spend so much time helping students "learn how to learn" and mentoring other educators, that this EdD seems like the perfect fit for me.

During a department meeting in May of 2019, we reviewed our program completion data, coupled with students' feedback surrounding their experiences in the CISL on-campus and online programs. Our findings indicated that many CISL online students were registering for only 3 credits per semester, if they registered at all, and the graduation rate was lower than we had anticipated, precisely because students were moving so slowly through the program. Many of our CISL online students are full-time working professionals who do not intend to pursue the professoriate; rather, many of them chose to pursue the doctorate to advance in their current positions and/or open up new opportunities to design strategies to impact problems of educational practice. As such, we identified the need to offer our students an applied, professional doctorate geared toward preparing scholar-practitioners to use evidence-based practices to challenge inequity and solve problems that education leaders face on a daily basis. This realization led to the design of our forthcoming EdD program in Learning and Teaching in Social Contexts, as well as our membership with CPED.

\section{Program Design}

As previously mentioned, through survey data collection and conversations with students, we realized that many of our CISL online students' professional backgrounds and career goals suggested that they might be better suited for a doctoral program that would allow them to collaborate across school, academic, and 
community boundaries to "blend their practical wisdom with their professional skills and knowledge to name, frame, and solve problems of practice" (CPED, 2010, para. 9). Since our existing EdD program in Elementary Education was receiving few applications in comparison to our multidisciplinary $\mathrm{PhD}$ program in CISL, we identified the need for a new program that would accommodate the coursework and experiential pursuits of a wider audience, as well as offer our CISL online students an applied alternative to a theoryoriented degree designed for aspiring researchers and academics. As such, the proposal for a newly designed EdD in Learning and Teaching in Social Contexts was born.

\section{Mission}

As part of our design process, it was imperative to articulate a Learning and Teaching in Social Contexts EdD program mission for our current $\mathrm{PhD}$ students interested in transitioning, as well as the competitive external candidates we may wish to admit upon final approval of the program. When we introduced the idea of a new EdD program in addition to our existing $\mathrm{PhD}$ programs during department meetings and one-on-one conversations in the spring of 2019, we learned that faculty and students felt unclear about the distinguishable differences between a $\mathrm{PhD}$ and $\mathrm{EdD}$. As a result, we decided that our mission should emphasize the EdD's practical focus on developing transformational leaders who design strategies to impact problems of practice. Accordingly, we wanted to assert that the $\mathrm{EdD} / \mathrm{PhD}$ distinction is based on the primary focus of the degree and does not suggest that problems of practice are disconnected from the application of theory. Ultimately, we established the following Learning and Teaching in Social Contexts EdD program mission:

Designed within an actionable, justice-focused framework, University at Buffalo's Doctor of Education in Learning and Teaching in Social Contexts blends contemporary theory and practice across synergistic learning experiences to produce the next generation of educational professionals dedicated to addressing emergent problems of practice.

\section{CPED Framework}

Following our institution's acceptance to the CPED consortium, during the summer of 2019, the Dean of the Graduate School of Education, our department chair, several senior faculty members in the Departments of Learning and Instruction and Educational Leadership and Policy, and a newly-appointed director of doctoral studies attended the June CPED convening. Although we brought ideas about our program's design, our interactions with experienced CPED members and an improved understanding of CPED's seven guiding principles provided us with the resources and cornerstones of our program's identity to ensure a methodical, rigorous, and leading-edge program blueprint.

Aligned with CPED's guiding principles (Carnegie Project on the Education Doctorate, 2009) and grounded in practice that emphasizes direct, vigorous action to generate educational change, our new EdD program:

- Is framed around questions of equity, ethics, and social justice to design strategies to impact complex problems of practice.
- Prepares leaders who can construct and apply knowledge to make a positive difference in the lives of individuals, families, organizations, and communities.

- Provides opportunities for candidates to develop and demonstrate collaboration and communication skills to work with diverse communities and to build partnerships.

- Provides field-based opportunities to analyze problems of practice and use multiple frames to design meaningful strategies.

- Is grounded in and develops a professional knowledge base that integrates both practical and research knowledge, that links theory with systemic and systematic inquiry.

- Emphasizes the generation, transformation, and use of professional knowledge and practice.

In relation to our new EdD's learning outcomes, our program will graduate scholar-practitioners who have demonstrated the ability to: (1) identify, contextualize, and propose strategies to impact problems of practice in varied educational contexts; (2) cultivate and sustain effective, inclusive, and justice-oriented educational communities; (3) disseminate research that serves to resolve critical educational problems; (4) demonstrate an understanding of the importance of equity and justice in shaping their approach(es) to solving problems of educational practice; and (5) apply critical inquiry to and through varied laboratories of practice.

\section{Improvement Science in Education}

Prior to joining CPED, we were unfamiliar with improvement science, or continuous improvement, as an approach to study and improve education programs and processes (Bryk, Gomez, Grunow, \& LeMahieu, 2017). Through our interactions with experienced CPED members and collaborative exploration of research and resources focused on improvement science, we began to understand its role in systems thinking, or how we see the system of complex organizational problems. While thinking about the relationship between improvement science and activism, it was critical to consider how this intersecting framework would shape our new EdD program's coursework and practicum experiences, especially while students focus their problems of practice. As we brainstormed what the content, conversations, and practical experiences might look like, we drew connections to students' systems thinking represented in Tinkler, Tinkler, Jagla, and Strait (2016):

The path to navigating through and grappling with my own intersectionality of identity and privilege has allowed me to acknowledge the ways in which individuals, including myself, work as part of the oppressive system, while continuing to question and understand the ways in which the system oppresses its people...this recognition is necessary if one is to ever work toward social change. (p. 77)

In the example [in the preceding paragraph], the student recognizes that they have a choice to make-if they choose to ignore their structural privileges, they are complicit in a system of inequality that privileges some at the expense of others. Furthermore, embedded within these narrative accounts is an emerging view that allowing oneself to exist with complacency in a system that attributes privilege to some over others will foreclose social change. (p. 77) 
Therefore, with a focus on double-loop learning, a critical feature of continuous improvement, our students will use theories of action - that is, the delivery models for theories of change - to expand their analytical frame and explicitly identify and challenge their own underlying assumptions and beliefs (Argyris, 1976). By using double-loop learning, an educational concept and process that teaches reflexivity, students will shift their focus from direct problem solving, and instead learn to examine their problems of practice from different angles and test holistic, wide-ranging changes (Argyris \& Schon, 1978). Throughout the process, students will use City, Elmore, Fiarman, Teitel, and Lachman's (2018) networked approach to improving teaching and learning by developing and testing theories of action that:

- Align intended theory with the realities of work within an educational organization.

- Connect strategy to the actions and relationships critical to effective instruction and student learning.

- Identify the mutual dependencies required to carry out complex improvement work.

- $\quad$ Are grounded in research and/or evidence-based practice.

- Begin with a statement of a causal relationship between what $\mathrm{l} /$ we do and what constitutes a productive result in the organization.

- Prioritize high-leverage practices for achievement and equity.
- $\quad$ Are powerful enough to transform programs and practices.

As a collaborative, relational, and transformative process that is equally shaped by the underlying theoretical perspectives and values with which we approach the pedagogical design of learning, network learning requires pervasive signature pedagogies that bridge theory and practice (Hodgson, McConnell, \& Dirckinck-Holmfeld, 2012).

\section{Signature Pedagogies}

To support students in their development and testing of theories of action, our program's signature pedagogies, or "the types of teaching that organize the fundamental ways in which future practitioners are educated for their new professions", include three dimensions: surface structure, deep structure, and implicit structure (Shulman, 2005, p. 52). While surface structures consist of concrete, operational acts of teaching and learning, showing and demonstrating, and questioning and answering; deep structures reflect a set of assumptions about how to best impart a body of knowledge and know-how (Shulman, 2005). The implicit structure includes "a moral dimension that comprises a set of beliefs about professional attitudes, values, and dispositions" (Shulman, 2005, p. 55). Throughout the program, faculty will mentor doctoral students through coursework and applied research experiences using a signature pedagogy comprised of three components: collaborative, inquiry-based learning; equity-driven, field-based research; and generative, transformative leadership (see Table 1 for additional details).

Table 1. Three-Component Signature Pedagogy

\begin{tabular}{|c|c|c|}
\hline Component & Scholar-Practitioner Development & Place in Program \\
\hline $\begin{array}{l}\text { Collaborative, } \\
\text { Inquiry-Based } \\
\text { Learning }\end{array}$ & $\begin{array}{l}\text { Inquiry as a teaching method seeks to develop inquirers and } \\
\text { use curiosity as motivators leading to learning through } \\
\text { personal engagement (Justice, Rice, Roy, Hudspith, \& } \\
\text { Jenkins, 2009). } \\
\text { Inquiry promotes the integration of theoretical and practical } \\
\text { knowledge through reflection and dialogue about existing } \\
\text { ideals of justice and equity (Lynn \& Smith-Maddox, 2007). }\end{array}$ & $\begin{array}{l}\text { Stage 1: Coursework centering on a } \\
\text { problem of practice (PoP) } \\
\text { Interdisciplinary courses prepare students } \\
\text { to define and address PoPs. }\end{array}$ \\
\hline $\begin{array}{l}\text { Equity-Driven, } \\
\text { Field-Based } \\
\text { Research }\end{array}$ & $\begin{array}{l}\text { Equity-minded practitioners: (1) use data and critical analysis } \\
\text { to uncover patterns of inequity in student outcomes; (2) are } \\
\text { race-conscious and consider the contemporary and historical } \\
\text { context of exclusionary practices in America's institutions of } \\
\text { higher education; (3) take personal and institutional } \\
\text { responsibility for their students' outcomes and critically } \\
\text { examine their own practices; (4) recognize and understand } \\
\text { that inequalities are perpetuated and compounded by the } \\
\text { interplay of institutional structures, policies, and practices that } \\
\text { are within their control; and (5) are accountable to and take } \\
\text { responsibility for closing student opportunity gaps (USC } \\
\text { Center for Urban Education, 2020). }\end{array}$ & $\begin{array}{l}\text { Stage 2: Design and research methods for } \\
\text { improving education } \\
\text { In combination with Stage 1, methods } \\
\text { courses enable students to develop } \\
\text { practice-based proposals and initiate } \\
\text { opportunities for change in educational } \\
\text { contexts. }\end{array}$ \\
\hline $\begin{array}{l}\text { Generative, } \\
\text { Transformative } \\
\text { Leadership }\end{array}$ & $\begin{array}{l}\text { Transformative leadership begins with questions of justice } \\
\text { and democracy; in practice, educational leaders create } \\
\text { inclusive and equitable opportunities that yield generative } \\
\text { impacts on learning environments (Shields, 2010). } \\
\text { Transformative leadership links education and educational } \\
\text { leadership with the wider social context within which it is } \\
\text { embedded; therefore, transformative leadership and }\end{array}$ & $\begin{array}{l}\text { Stage 3: Dissertation in Practice (DiP) } \\
\text { In combination with Stages } 1 \text { and 2, } \\
\text { students develop a DiP or public statement } \\
\text { of doctoral quality research, that } \\
\text { demonstrates scholarly rigor and } \\
\text { practitioner relevance. }\end{array}$ \\
\hline
\end{tabular}




\begin{tabular}{|l|l|l|}
\hline & $\begin{array}{l}\text { leadership for inclusive and socially just learning } \\
\text { environments are inextricably related (Shields, 2010). }\end{array}$ & \\
\hline
\end{tabular}

\section{Promoting Activism Through Curriculum}

As dedicated members of CPED, we are committed to aligning our new program with the consortium's guiding principles to support quality, rigorous practitioner preparation while honoring the local context of our students' communities. Focused by a lens of justice and an improvement science framework, our new program is designed to empower and equip students to lead proactive and responsive systemic change using problem-solving approaches centered on continuous inquiry and learning. Throughout our three cross-cutting program stages - (1) coursework centering on a problem of practice; (2) design and research methods for educational improvement; (3) dissertation in practice - students will harness their own transformative power to conduct applied research to unique problems of practice in their communities (Figure 1). Our students will employ justice-driven methods derived from iterative inquiry cycles to advocate for diversity and equitable educational practices beyond paradigmatic lines such as race, gender, and sexual orientation inclusivity; they will move beyond knowledge consumption to knowledge production and champion diversity in educational practice as difference in approach, attitude, and perspective.

Figure 1. Cross-Cutting Program Stages and Experiences

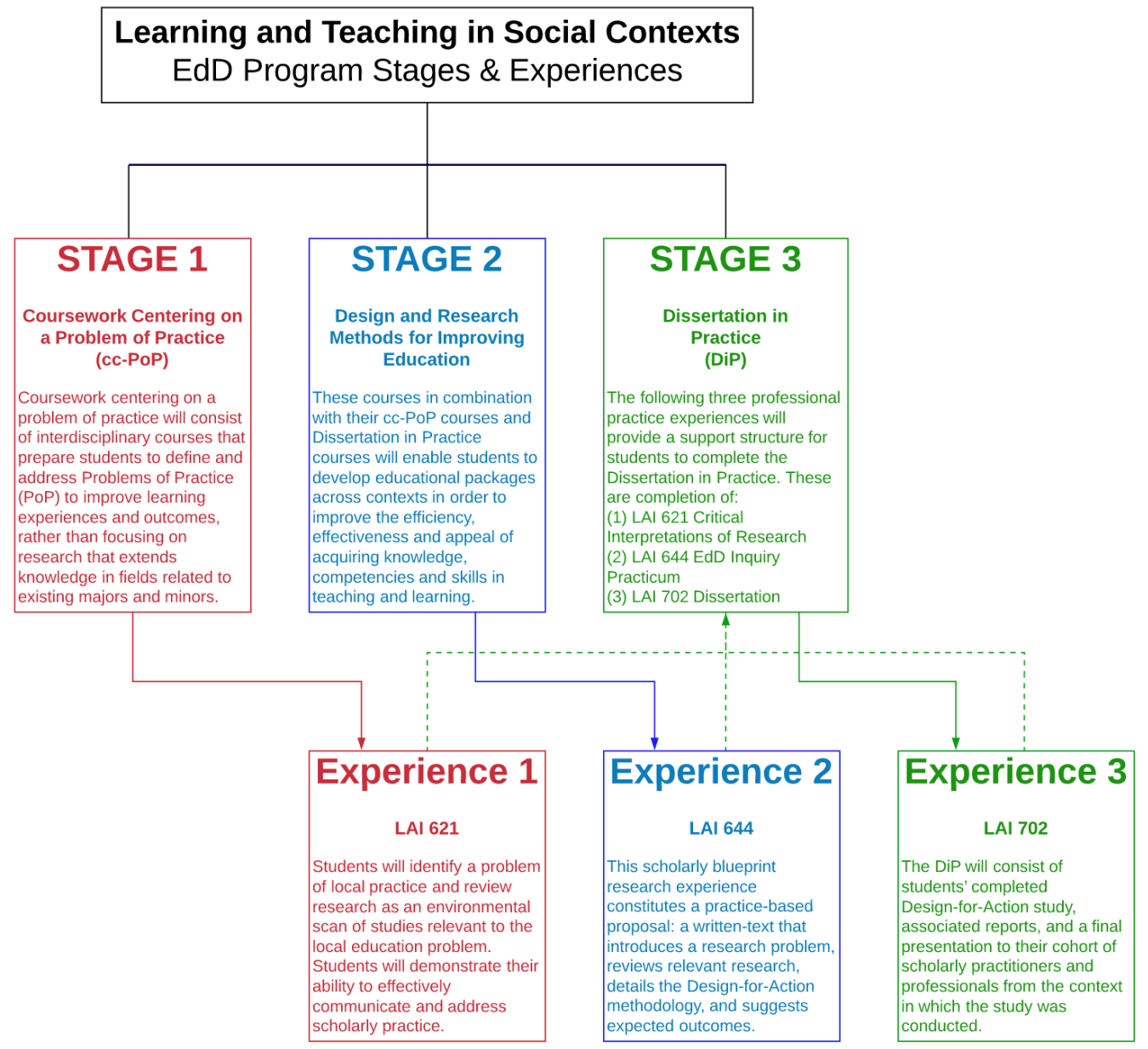

Throughout the program, students will engage in collaborative, inquiry-based coursework centering on problems of practice and equity-driven, field-based research experiences. Adapted from fellow CPED institutions' program literature and models (e.g., Florida State University), students' rigorous preparation will culminate in a Dissertation in Practice (DiP) designed to yield generative impacts and demonstrate each scholar-practitioner's commitment to transformative leadership within and across educational contexts.

Chapter 1 of the DiP will provide a clear articulation of the problem of practice, explanations of the purpose and significance of the study, a description of the study site(s), and research question(s) that are evidently connected to the purpose statement. In their development of Chapter 1 , through a lens of equity and justice, students will identify and define a problem of practice using collaborative inquiry, as well as address one or more cultural dimensions of power that are influenced by the proposed problem of practice. 
Similar to a review of literature, Chapter 2 will provide a background analysis of previous research related to the problem of practice. While Chapter 2 is expected to begin with a broader analysis of the educational landscape in which the problem of practice is situated, it will also include a description of the study context that connects to a rationale for proposed research and addresses inequitable power structures between communities. Ultimately, Chapter 2 will demonstrate how the problem of practice is informed by: (1) social theories and epistemological frameworks; (2) a critical review of data through multidisciplinary lenses; and (3) a critical review of data across community boundaries.

Chapter 3 is the DiP version of a traditional methodology chapter; that is, the investigative approach designed to answer the research question(s). Chapter 3 will include information that informs questions such as: Which methodological approach(es) were used?; Who and/or what were the data sources and how and/or why were they selected?; Which method(s) of data collection were used?; How were data analyzed?; How were methodological choices evaluated and justified? In their development of Chapter 3, students will defend their use of a design for action that is: (1) situated within theoretical and empirical antecedents; (2) creates generative opportunities for change; (3) seeks to confront and transform status quo practices; and (4) advocates for educational equity in the service of learners.

Lastly, Chapter 4 will provide a focused summary of the entire DiP, including study findings, implications, recommendations for future research, and a dissemination plan that describes how the research will be shared to promote generative impacts and transformative leadership across educational contexts. Upon completion of Chapter 4, students will have argued compellingly that their research: (1) leverages opportunities for the aims of educational improvement; (2) supports the establishment and advancement of networked improvement communities; and (3) addresses a moral, ethical, and political vision that advocates for equity and justice within and across milieus of teaching and learning. An overview of the program exam stages and DiP chapter expectations is provided in Table 2.

Table 2. Overview of Exam Stages and Dissertation in Practice Chapters

\begin{tabular}{|c|c|c|}
\hline Exam Stage & Required Components & Expected Completion Date \\
\hline $\begin{array}{l}\text { Prequalifying } \\
\text { Paper }\end{array}$ & $\begin{array}{l}\text { 10-page essay } \\
\text { Problem of Practice statement } \\
\text { Description of context } \\
\text { Draft research questions } \\
\text { Defense of } 10 \text {-page essay } \\
\text { Evaluated by advising faculty }\end{array}$ & $\begin{array}{l}\text { End of Spring } 1 \text { (Year } 1 \text { ) } \\
\text { Summer } 2 \text { Week } 4\end{array}$ \\
\hline Qualifying Paper & $\begin{array}{l}\text { DiP Chapters } 1 \& 2 \text { drafts } \\
\text { Chapter 1: PoP Statement, Purpose, Research Questions } \\
\text { Chapter 2: Background Analysis (or Review of Literature) } \\
\text { 2-page methodology overview }\end{array}$ & $\begin{array}{l}\text { Fall } 2 \text { Week } 4 \\
\text { Fall } 2 \text { Week } 4\end{array}$ \\
\hline $\begin{array}{l}\text { Proposal } \\
\text { Defense }\end{array}$ & $\begin{array}{l}\text { DiP Chapters } 1 \text { \& } 2 \text { summary } \\
\text { DiP Chapter } 3 \text { draft } \\
\text { Pre-recorded 20-minute presentation of DiP Chapter } 3 \\
\text { Chapter 3: Investigative Approach (or Methodology) } \\
\text { Projected timeline for DiP draft completion } \\
\text { Organized in consultation with advising faculty } \\
\text { Synchronous oral defense of items } 1-4 \\
\text { Evaluated by advising faculty }\end{array}$ & $\begin{array}{l}\text { Complete items } 1-5 \text { by End of } \\
\text { Spring } 2 \text { (Year 2) }\end{array}$ \\
\hline $\begin{array}{l}\text { Dissertation in } \\
\text { Practice }\end{array}$ & $\begin{array}{l}\text { DiP Chapter 1: PoP Statement, Purpose, Research Questions } \\
\text { DiP Chapter 2: Background Analysis (or Review of Literature) } \\
\text { DiP Chapter 3: Investigative Approach (or Methodology) } \\
\text { DiP Chapter 4: Findings, Implications, Recommendations, Dissemination Plan }\end{array}$ & $\begin{array}{l}\text { Complete drafts of items 1-4 } \\
\text { by Spring } 3 \text { Week } 4\end{array}$ \\
\hline $\begin{array}{l}\text { Dissertation in } \\
\text { Practice } \\
\text { Defense }\end{array}$ & $\begin{array}{l}\text { DiP Chapter } 4 \text { summary } \\
\text { Pre-recorded 20-minute presentation of DiP Chapter } 4 \\
\text { Executive summary of DiP } \\
\text { Projected timeline for DiP completion } \\
\text { Includes revisions recommended by advising faculty } \\
\text { Organized in consultation with advising faculty } \\
\text { Synchronous oral defense of items } 1-4\end{array}$ & $\begin{array}{l}\text { Final drafts of items } 1-5 \text { by } \\
\text { End of Spring } 3 \text { (Year } 3 \text { ) }\end{array}$ \\
\hline
\end{tabular}




\section{ANTICIPATED BENEFITS AND LIMITATIONS OF OUR MODEL}

A key benefit of our model is that the University at Buffalo recruits students from diverse educational settings, including fields such as nursing, nutrition, and counseling; in addition to more traditional K-12 and post-secondary educational contexts. Despite their wide-ranging fields, our students share a common commitment to learning and serving as transformational leaders. Since our program structure allows completion in three full years of part-time study, including summer-term enrollment, our model will accommodate the needs of working professionals through customized learning plans, structured timelines, and an online delivery format.

Conversely, a potential limitation of our model is its fully online format. Faculty who are coordinating and teaching within the program will be responsible for cultivating a collaborative, transcultural community for EdD students. As with all fully online learning initiatives, building relationships presents particular challenges.

\section{LESSONS LEARNED}

Prompted by the needs of our students and doctoral-level program goals of our department, our program redesign received unanimous support from department faculty, chair, and the Dean of the Graduate School of Education. Rather than limit our program to students who are interested in elementary education, our new program in Learning and Teaching in Social Contexts will attract and welcome students from wide-ranging educational disciplines and contexts. Furthermore, with the addition of CPED's guiding principles, students will graduate from our new EdD program with justice-focused knowledge, professionalism, and expertise to initiate and sustain improvement efforts that reduce educational inequities.

Throughout the redesign process, we learned that continuous improvement is best informed by dialogue with all stakeholders across multiple contexts including, but not limited to: students, faculty, post-graduation career interests and opportunities, and the fields - in our case, curriculum and instruction and learning sciences. Lessons learned from our current doctoral students and our experiences with advising and teaching in the CISL PhD program allowed us to identify the need and opportunity to balance the instrumental versus exploratory orientation of our new EdD program. Now, with a clearer understanding of their practice-focused research interests and the careers that some of our current doctoral students and prospective $\mathrm{EdD}$ candidates are aspiring towards, we are wellpositioned to launch an EdD program that is responsive to our students' academic and vocational pursuits.

In addition to foregrounding our EdD's learning outcomes in CPED's guiding principles and equipping our students with the competencies necessary to re(enter) educational contexts as scholar-practitioners, our new program will offer working professionals the flexibility to complete the EdD through a part-time, fully online delivery model. With hopes of attracting and enrolling students from global contexts and wide-ranging educational disciplines through our cohort model, our students will be equipped with the methodological knowledge to advocate for justice, equity, and diversity in educational settings. With the support of our students and colleagues, as well as the knowledge gleaned from our membership with CPED, we are ready and eager to prepare the next generation of education activists who will enrich and vitalize our interdisciplinary department.

\section{RECOMMENDATIONS}

Based on lessons learned, our new EdD program is grounded in the fact that professional consortiums like CPED provide a model for evidence-based practices to scholar-practitioner preparation. Therefore, in order to sustain an EdD program's commitment to quality, rigorous practitioner preparation, we recommend the following:

1. Conducting a regular program review and revision process that includes multiple stakeholders and maintains a justicefocused orientation. Ensuring that the review process is consistent and inclusive serves dual purposes. It promotes aspirations toward excellence and removes barriers associated with organizational change. Further, when criteria and practices related to review are grounded in principles rooted in justice, program revisions will necessarily reflect this commitment.

2. Centering program outcomes and assessments on equity and justice as defined by multiple stakeholders. Review and revision processes cannot be simply overlaid onto existing programs. To be effective, reorientation toward equity and justice must be built into program outcomes, course objectives, and students and program assessments. This endeavor requires collaboration among stakeholders to be initial and ongoing. That is, it involves careful consideration of the program at the outset, as well as continuous efforts to engage diverse stakeholder groups to critically evaluate program goals and outcomes.

3. Organizing and sustaining a student-faculty advisory board to learn about students' ongoing program needs and expectations as well as emerging trends. Resource allocation is a window into values. To see what matters, look for where time, money, and resources - human and otherwise - are dedicated. Without oversight, it can be easy for administrative considerations to overshadow the most noble intentions. A student-faculty advisory board can extend the perspective of oversight and help to assure that opportunity, equity, and justice retain primacy in program development, implementation, and evaluation.

4. Establishing a culture of collaborative professionalism prior to admission, throughout the three-year program, and as a sustaining professional network post-graduation.

Developing a culture of collaborative professionalism requires sustained attention from recruitment through admission, as well as beyond program completion. Clarity of purpose with respect to a commitment to equity and justice must be established prior to admission and supported throughout program coursework. Tenets of collaborative professionalism can be upheld by including collaborative activities as part of the application process, and by scaffolding application materials to be educative with respect to the program. In short, the application experience can mirror the culture and mission of the program.

The lessons and recommendations, like any learning experience, are multidimensional, recursive, and mutually 
informative. They are context-dependent and informed by the stakeholders who inhabit their learning communities. While justice is ultimately aspirational, as long as injustice exists, educators have an obligation to be transformational, and to prepare activists committed to constructing a future that is more just than the present.

\section{REFERENCES}

Allen, I. E, \& Seaman, J. (2011). Going the distance: Online education in the United States. The Online Learning Consortium. Retrieved from http://sloanconsortium. org/publications/survey/going_distance_2011

Allen, I. E., \& Seaman, J. (2017). Digital learning compass: Distance education enrollment report 2017. Wellesley: Babson College/eLiterate/WCET

Argyris, C. (1976). Increasing leadership effectiveness. New York, NY: Wiley.

Argyris, C. \& Schon, D. A. (1978). Organizational learning: A theory of action perspective. Reading, MA: Addison Wesley.

Bryk, A. S., Gomez, L. M., Grunow, A., \& LeMahieu, P. G. (2017). Learning to improve: How America's schools can get better at getting better. Cambridge, MA: Harvard Education Press.

Carnegie Project on the Education Doctorate. (CPED). (2009). Retrieved from https://www.cpedinitiative.org/

Carnegie Project on the Education Doctorate. (CPED). (2010). CPED design concepts. Retrieved from

https://c.ymcdn.com/sites/cpedinitiative.siteym.com/resource/resmgr/CP ED_Framework.pdf

Chaney E. G. (2001). Web-based instruction in a rural high school: A collaborative inquiry into its effectiveness and desirability. NASSP Bulletin, 85(628), 20-35.

City, E. A., Elmore, R. F., Fiarman, S. E., Teitel, L., \& Lachman, A. (2018). Instructional rounds in education: A network approach to improving teaching and learning. Cambridge, MA: Harvard Education Press.

Gilbert, B. (2015). Online learning revealing the benefits and challenges. Education Masters. Paper 303. Retrieved from https://fisherpub.sjfc.edu/education_ETD_masters/303

Halupa, C., \& Bolliger, D. U. (2013). Student perceptions on the utilization of formative feedback in the online environment. International Journal of Online Pedagogy and Course Design (IJOPCD), 3(2), 59-76. doi:10.4018/ijopcd.2013040104
Hodgson, V., McConnell, D., \& Dirckinck-Holmfeld, L. (2012). The theory, practice and pedagogy of networked learning. In L. Dirckinck-Holmfeld, V. Hodgson \& D. McConnell (Eds.), Exploring the theory, pedagogy and practice of networked learning (pp. 291-305). New York, NY: Springer.

Justice, C., Rice, J., Roy, D., Hudspith, B., \& Jenkins, H. (2009). Inquiry-based learning in higher education: Administrators' perspectives on integrating inquiry pedagogy into the curriculum. Higher Education, 58, 841-855.

Levine, A. (2005). Educating school leaders. The education schools project. New York, NY: Columbia University Teachers College.

Lynn, M., \& Smith-Maddox, R. (2007). Preservice teacher inquiry: Creating a space to dialogue about becoming a social justice educator. Teaching and Teacher Education, 23, 94-105.

Shields, C. M. (2010). Transformative leadership: Working for equity in diverse contexts. Educational Administration Quarterly, 46(4), 558-589. https://doi.org/10.1177/0013161X1037560

Shulman, L. (2005). Signature pedagogies in the professions. Daedalus, 134(3), 52-59. doi: 10.1162/0011526054622015.

Shulman, L. S., Golde, C. M., Bueschel, A. C., \& Garabedian, K. J. (2006). Reclaiming education's doctorates: A critique and a proposal. Educational Researcher, 35(3), 25-32.

Snyder, T.D., de Brey, C., and Dillow, S.A. (2019). Digest of education statistics 2017 (NCES 2018-070). National Center for Education Statistics, Institute of Education Sciences, U.S. Department of Education. Washington, DC.

Tinkler, A. S., Tinkler, B. E., Jagla, V. M., \& Strait, J. (2016). Service-learning to advance social justice in a time of radical inequality. Charlotte, NC: Information Age Publishing, Inc.

U.S. Bureau of Labor Statistics. (2015, July 2). Time spent working by full- and part-time status, gender, and location in 2014. Retrieved from https://www.bls.gov/opub/ted/2015/time-spent-working-by-full-and-parttime-status-gender-and-location-in-2014.htm

U.S. Department of Education, Office of Planning, Evaluation, and Policy Development, Evaluation of Evidence-Based Practices in Online Learning: A Meta-Analysis and Review of Online Learning Studies, Washington, D.C., 2010. Retrieved from https://www2.ed.gov/rschstat/eval/tech/evidence-basedpractices/finalreport.pdf

USC Center for Urban Education. (2020, January 9). Equity Mindedness. Retrieved from https://cue.usc.edu/about/equity/equity-mindedness/ 